\title{
Reading Scientific Texts: Adapting Primary Literature for Promoting Scientific Literacy
}

\section{Guest Editorial}

\author{
Anat Yarden \\ Published online: 19 February 2009 \\ (C) Springer Science + Business Media B.V. 2009
}

This special issue of Research in Science Education focuses on the reading of scientific texts in general, and on the adaptation of primary scientific literature for promoting scientific literacy among high-school science students in particular. Since several scientific text genres are mentioned extensively throughout this issue, the aim of this brief editorial section is to provide a framework that will enable the reader to easily distinguish between them. This is followed by a brief outline of the special issue.

\section{Distinguishing Between Various Scientific Text Genres}

Goldman and Bisanz (2002) previously suggested that "there are three major roles of communication of scientific information in our society. The first is communication among scientists; the second is...popularizing information generated by the scientific community; the third is providing formal education..." (p. 21). Of the various examples of the three types of communication outlined by Goldman and Bisanz (2002), I refer here to Primary Scientific Literature (PSL), Journalistic Reported Versions (JRV) and Textbooks as representative genres of each of those communication types, respectively. Various attributes of these three genres are presented in Table 1, alongside the one which is the focus of this issue, namely Adapted Primary Literature (APL). A comparison of the genres outlined in Table 1 enables viewing APL in the context of the other, better known genres, and appreciating its characteristics.

A careful examination of the four genres presented in Table 1 reveals a trend in the adaptation process of primary scientific texts, from more to less scientific types of communication. In the far left column, the PSL text represents the genre of communication among scientists. This type of text is written by scientists for scientists. It uses mainly an argumentative genre, includes evidence to support conclusions (mainly in the Methods and Results sections), is constructed in a canonical manner (Abstract, Introduction, Methods,

\footnotetext{
A. Yarden $(\bowtie)$

Department of Science Teaching, Weizmann Institute of Science, Rehovot 76100, Israel e-mail: anat.yarden@weizmann.ac.il
} 


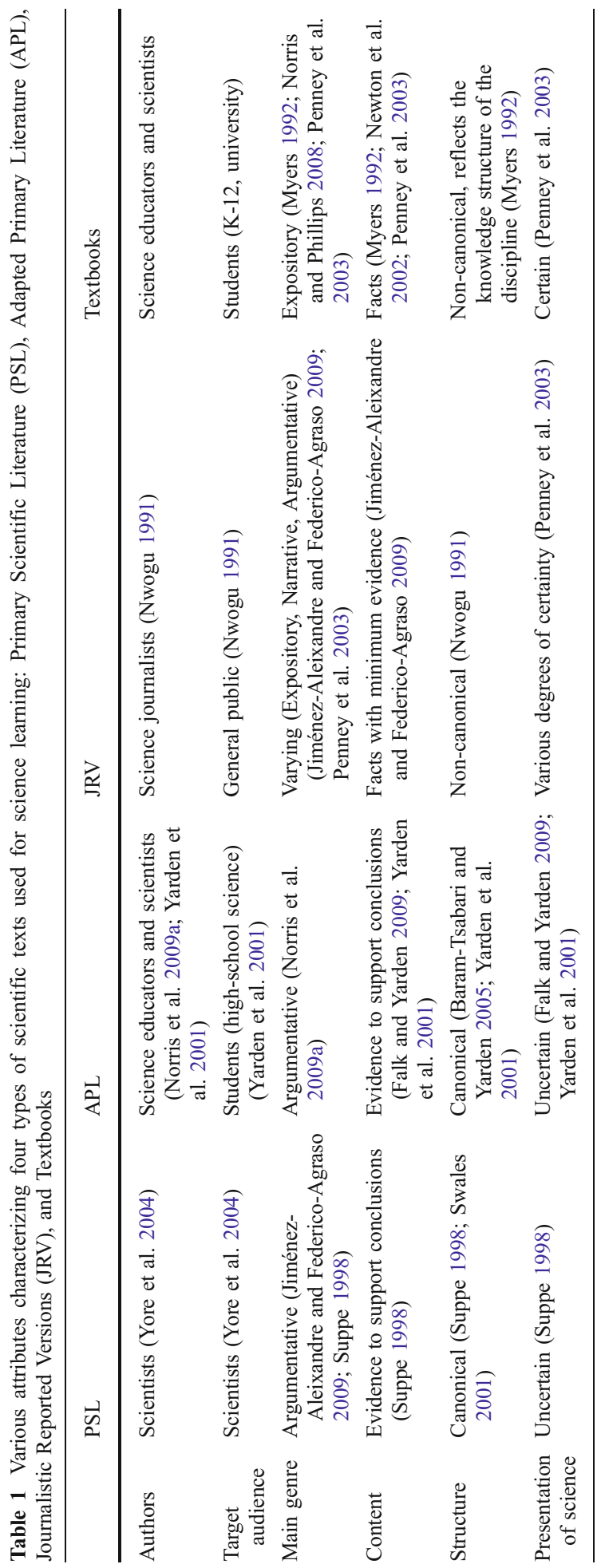


Results, Discussion), and presents the uncertain aspects of science (Table 1). In contrast, in the far right column, the textbook genre represents the genre of communicating scientific information in the educational system. Textbooks for the K-12 levels are usually written by science educators and science writers. ${ }^{1}$ They are usually written using an expository genre, which often includes facts with minimal evidence to support conclusions. They are frequently structured in a way that reflects the knowledge structure of the discipline and present the certain aspects of science (Table 1). These two extremes reflect the contrast between "real science", as it is communicated in each scientific discipline, and "school science", as it is communicated to students in schools.

In the two columns in the middle of Table 1, two different adaptations of PSL are presented, JRV and APL. JRV is somewhat closer to the textbook genre in that it is not structured in a canonical manner, contains mainly facts with minimum evidence to support them, and presents the scientific knowledge with various degrees of certainty. In contrast, the APL is somewhat closer to the PSL in all the parameters examined here, apart from the fact that it is usually not written by the scientists that conducted the research and that its target audience consists of high-school science students (Table 1). These two genres represent two different types of text that can serve two different purposes. The JRV genre is important for students as life-long learners, as they are most likely to encounter this genre as a major source of new scientific information following their formal education. APL, on the other hand, is a unique genre developed to enable the use of PSL for learning science in high school. It aims to represent "real science" in schools and to promote important aspects of high-school students' scientific literacy that are harder to achieve using textbooks or JRV.

It has long been argued that "many science curricula...do not take into account the practical reasoning required in scientific knowledge production" (Norris 1992, p. 196). Considering the various attributes that characterize the four types of texts discussed above, it is reasonable to assume that the use of argumentative scientific texts, like APL, might be useful in promoting the incorporation of scientific reasoning into the school curriculum. The authors of this special issue examine this assumption, as outlined below.

\section{Outline of the Special Issue}

This special issue evolved from a symposium that took place during the recent annual meeting of the National Association of Research in Science Teaching (Phillips et al. 2008). This symposium brought together researchers who have begun to examine the use of the PSL genre for high-school science learning in various settings and formats. This special issue includes four of the five papers that were presented at this symposium (the fifth paper is published elsewhere, Falk et al. 2008), as well as the discussions that followed the paper presentations.

In the first paper, Phillips and Norris (2009) argue that reading scientific texts is an inquiry activity which could become part of school science instruction through the use of APL. The subsequent three papers provide three different examples in which attempts have been made to realize this vision: i) Norris et al. (2009a) describe initial attempts to examine the enactment of a prototype APL in mathematical biology that is available as a web-based resource which includes supplemental pedagogical units; ii) Jiménez-Aleixandre and

\footnotetext{
${ }^{1}$ For the university level, scientists are often the writers of textbooks, but this is not the focus of this editorial, and will not be discussed further.
} 
Federico-Agraso (2009) compare the argumentative and persuasive structures of a PSL article about human cloning, JRVs of the same article, and students' summaries of one of those JRVs; iii) Falk and Yarden (2009) discuss the discourse developed during the enactment of an article from an APL-based curriculum in biotechnology in one class, and examine the epistemic practices used by students during their meaning-making of the Results and Discussion sections of the article. The papers are followed by discussions and rejoinders (Ford 2009; Norris et al. 2009b; Osborne 2009; Yarden et al. 2009). Taken together, the papers and the discussions provide the current state of the art with regards to the use of APL for science learning.

Acknowledgments I thank Ayelet Baram-Tsabari, Hadas Gelbart, Rachel Cohen, Hedda Falk and Maria Pilar Jiménez-Aleixandre for their useful comments. AY is the incumbent of the Helena Rubinstein Career Development Chair.

\section{References}

Baram-Tsabari, A., \& Yarden, A. (2005). Text genre as a factor in the formation of scientific literacy. Journal of Research in Science Teaching, 42(4), 403-428.

Falk, H., \& Yarden, A. (2009). "Here the scientists explain what I said." Coordination practices elicited during the enactment of the Results and Discussion sections of adapted primary literature. Research in Science Education, Published Online. doi:10.1007/s11165-008-9114-9.

Falk, H., Brill, G., \& Yarden, A. (2008). Teaching a biotechnology curriculum based on adapted primary literature. International Journal of Science Education, 30(14), 1841-1866.

Ford, D. J. (2009). Promises and challenges for the use of adapted primary literature in science curricula: commentary. Research in Science Education, Published Online. doi:10.1007/s11165-008-9115-8.

Goldman, S. R., \& Bisanz, G. L. (2002). Toward a functional analysis of scientific genres: Implications for understanding and learning processes. In J. Otero, J. A. Leon, \& A. C. Graesser (Eds.), The psychology of text comprehension. Mahwah, NJ: Lawrence Erlbaum.

Jiménez-Aleixandre, M. P., \& Federico-Agraso, M. (2009). Justification and persuasion about cloning: Arguments in Hwang's paper and journalistic reported versions. Research in Science Education, Published Online. doi:10.1007/s11165-008-9113-x.

Myers, G. A. (1992). Textbooks and the sociology of scientific knowledge. English for Specific Purpose, 11, 3-17.

Newton, L. D., Newton, D. P., Blake, A., \& Brown, K. (2002). Do primary school science books for children show a concern for explanatory understanding? Research in Science and Technological Education, 20 (2), 227-240.

Norris, S. P. (1992). Practical reasoning in the production of scientific knowledge. In R. A. Duschl \& R. J. Hamilton (Eds.), Philosophy of science, cognitive psychology, and educational theory and practice (pp. 195-225). Albany, NY: State University of New York Press.

Norris, S. P., \& Phillips, L. M. (2008). Reading as inquiry. In R. A. Duschl \& R. E. Grandy (Eds.), Teaching scientific inquiry: recommendations for research and implementation (pp. 233-262). Rotterdam, NL: Sense Publishers.

Norris, S. P., Macnab, J. S., Wonham, M., \& de Vries, G. (2009a). West Nile virus: Using adapted primary literature in mathematical biology to teach scientific and mathematical reasoning in high school. Research in Science Education, Published Online. doi:10.1007/s11165-008-9112-y.

Norris, S. P., Falk, H., Federico-Agraso, M., Jiménez-Aleixandre, M. P., Phillips, L. M., \& Yarden, A. (2009b). Reading science texts - epistemology, inquiry, authenticity - A rejoinder to Jonathan Osborne. Research in Science Education, doi:10.1007/s11165-008-9118-5.

Nwogu, K. N. (1991). Structure of science popularizations: A genre-analysis approach to the schema of popularized medical texts. English for Specific Purpose, 10, 111-123.

Osborne, J. (2009). The potential of adapted primary literature (APL) for learning: A response. Research in Science Education, doi:10.1007/s11165-008-9117-6. 
Penney, K., Norris, S. P., Phillips, L. M., \& Clark, G. (2003). The anatomy of junior high school science textbooks: An analysis of textual characteristics and a comparison to media reports of science. Canadian Journal of Science, Mathmatics and Technology Education, 3(4), 415-436.

Phillips, L. M., \& Norris, S. P. (2009). Bridging the gap between the language of science and the language of school science through the use of adapted primary literature. Research in Science Education, Published Online. doi:10.1007/s11165-008-9111-z

Phillips, L. M., Yarden, A., Falk, H., Norris, S. P., Jiménez-Aleixandre, M. P., \& Ford, D. J. (2008). Reading scientific texts: Adapting primary literature for promoting scientific literacy. (Symposium presented at the NARST Annual International Conference: Impact of Science Education Research on Public Policy, Baltimore, MD).

Suppe, F. (1998). The structure of a scientific paper. Philosophy of Science, 65, 381-405.

Swales, J. M. (2001). Genre analysis: English in academic and research settings. Cambridge: Cambridge University Press.

Yarden, A., Brill, G., \& Falk, H. (2001). Primary literature as a basis for a high-school biology curriculum. Journal of Biological Education, 35(4), 190-195.

Yarden, A., Falk, H., Federico-Agraso, M., Jiménez-Aleixandre, M. P., Norris, S. P., \& Phillips, L. M. (2009). Supporting teaching and learning using authentic scientific texts: A rejoinder to Danielle J. Ford. Research in Science Education, doi:10.1007/s11165-008-9116-7.

Yore, L. D., Hand, B., Goldman, S. R., Hildebrand, G. M., Osborne, J. F., \& Treagust, D. F. (2004). New directions in language and science education research. Reading Research Quarterly, 39(3), 347-352. 